\title{
Economic Development with Creative Tourism Reflection of Iran's Facts
}

\author{
Abdol Aziz Shahraki* \\ Department of Archaeology, Sweden
}

Submission: May 30, 2018; Published: July 19, 2018

*Corresponding author: Abdol Aziz Shahraki, Department of Archaeology, Sweden, Email: sharaki@kth.se

\begin{abstract}
This study is about creative tourism on a global scale and analyzes a local handicraft industry. These are questions, which this article responses: Is it possible to develop the creative tourism with the help of qualitative and quantitative improvements of handicrafts? How could Iran acquire a greater share in the global tourism? Thus, the purpose of this research is to find a procedure for increasing Iran's share of global tourism. The study assumes that Iran with the help of its tourism resources' advantages can make socioeconomic development. The method of this applied research is an analytic one, which uses statistical techniques. First, this method supplies a theoretical foundation to answer the above-mentioned questions. Then, this research assesses the validity of the theories and assumptions with the help of a case study in Shiraz city. Finally, the study presents its outcomes. The results show that if we solve the problems related to the processes of handicraft productions, the creative tourism industry will bloom, and Iran gains a greater share of the industry. The procedures to develop the creative tourism that this paper presents are feasible to similar cities everywhere.
\end{abstract}

Keywords: Creative tourism; Handicrafts industries; Tourism resources; Tourism marketing; Tourism development; Shiraz; Bloom; Global scale; Social Sciences; Open ateliers; Century; Culture; Arts; Climates; Livelihoods; Environments; Global reputation

\section{Introduction}

Oxford English Dictionary defines the noun of tourism, as 'travel for pleasure'. Traveling has always been a human need. Seeing everywhere, pry, and understanding other civilizations are development motors of communities. Nevertheless, types of tourists and their motivations have always been under change. Patterns and systems of tourism are varying by the time passing. The changes are caused by various livelihoods and cultures of the regions. Different environments, climates, natural systems and people make the varieties. Theses diversities enhance the contents of sociocultural systems too. Such dissimilarities make foundations for innovations and creativity. Handicraft productions are the result of the creativity. Today, the tourism industry, particularly the creative tourism, is a key to developments in major countries, especially underdevelopment countries. According to statistics and reports, the tourism industry is the biggest and progressive industry on a global scale [1]. For this reason, an important objective of UNESCO is helping the creative tourism. The aim of the organization is to assist areas that are suitable tourism destinations. It also works to increase the competition ability of those areas to attract tourists through creativity and innovation. Although, handicraft industries are set in light industrial categories, but their economic role is significant. Handicraft industries are creative industries, which underdevelopment countries have a bigger share in those compared to advanced countries. Many cities in Iran due to various climates, living conditions and advantages have excellent ability to attract tourists in creative handicrafts and increase the tourism value chain. Iranian artists have a global reputation and a noble competitive ability in this scope.

The purpose of this paper is to examine the role of the creative handicraft industries in developing the tourism. The aim is to discover the industry's current problems and find ways to improve it to gain a greater share of the global tourism economy. Therefore, this study plans to find ways to increase the share of Iran in the global tourism industry and to improve the socioeconomic development of the country. The method used in this research paper is an analytic method of applied type. First, it has supplied theoretical foundations for the research. Then, we conducted field observations with the help of a questionnaire and interviews. In the latter phase, we tested the theories and the hypothesis in the field studies as a case study in Shiraz city.

This paper consists of six parts. After this introductory part, the second part of this study sets theoretical grounds for this research. The third part explains the methods of this research. The fourth section of the paper proves the accuracy of the hypothesis and theories suggested by this paper. The fifth part 
analyses and discusses on the findings of this research and final section presents outcomes and conclusions.

\section{Research Methods}

This research, as an applied and analytic study uses both a theoretical method and a field observation as a case study strategy. Its theoretical part explores ideas and theories, which have been presented by the scholars of the tourism industry. The purpose of this part is to supply a theoretical foundation for this research to find ways towards economic development through blooming of the creative tourism. We performed the field study with the help of a questionnaire and structured interviews to both tourists and responsible people, who are involved in the tourism activities. We analyzed the effective variables in handicraft industries with the help of a non-parametric statistical test, which had been developed by Milton Friedman. The statistical test has been called for Friedman test [2]. The statistical society in this research is foreign tourists, who have visited Shiraz handicraft industries. Shiraz is a metropolis in center southern part of Iran. We calculated and determined a sample size equal to 200 respondents, which covered tourists from all origins to Shiraz. Then, we obtained the necessary information from the questionnaire. We analyzed the collected data with the help of Spearman's rank correlation coefficient, r_S, and Friedman test. The Statistical Package for the Social Sciences (SPSS) has been a helpful assistant toll during our analysis. To determine the validity and reliability of the hypothesis, we used the coefficient of Cronbach's alpha to see the score of the dependency among the considered variables. Shiraz is a good sample to implement the case studies in it because Shiraz usually has many tourists, but its potential for tourism has yet not been used fully.

\section{Theoretical Foundation of this Research}

\section{The Economic Importance of the Tourism Industry}

Theoretically, the tourism industry has been introduced as an important industry to make economic growth and development. Major scholars in this field are arguing that in today's global economy, both in advanced and underdevelopment countries, the tourism industry is an economic development device, i.e. see [3-8]. As UNWTO reported, the tourism industry has increased during the last half century and accelerated in recent years. Statistics illustrate that the number of tourists increased $4 \%$ in the year of 2012 compared to 2011 and exceeded one billion tourists so that it jumped to 1035000000 . Projections suggested that this industry would also increase similarly in 2013, but the statistics show yet more progress and achieved to 1086750000 tourists with the help of a 5\% increase [9]. According to the statistics and reports, the tourism industry has become a major moneymaker and high-income industry in the world scale $[10,11]$. Kabbasi reported that the tourism industry composes $11 \%$ of the gross production and $5 \%$ of exports in the world. Kabbasi said also that $5 \%$ of global investment is in this industry $[12,13]$. Greg Richards wrote, 'Culture and tourism were two of the major growth industries of the 20th century' [14]. The exploration of the scholars' theories indicates that the tourism industry in addition to the quantitative efforts goes on towards qualitative and creative trends. Lee and Lee studied the change paradigm of the tourism industry, which is shifting from traditional tourism to creative tourism, see Table 1 . As illustrated by Table 1 the network era tourism has been characterized by the fact that creative tourists try to participate in local cultures and experience creative activities in local sites.

Table 1: Changes of tourism trends [21].

\begin{tabular}{|c|c|c|}
\hline Characteristics of tourism & Era & $\begin{array}{c}\text { Tourism } \\
\text { typologies }\end{array}$ \\
\hline Package tour & Industrial era & Mass tourism \\
\hline Tangible Heritage & $\begin{array}{c}\text { Late industrial } \\
\text { era }\end{array}$ & Culture tourism \\
\hline $\begin{array}{c}\text { Intangible heritage like } \\
\text { tourists' participation in the } \\
\text { local activities }\end{array}$ & Network era & Creative tourism \\
\hline
\end{tabular}

\section{Principles and Resources of A Creative Tourism Industry}

Creative tourism has existed as a form of cultural tourism since the initial beginnings of tourism itself [15]. As a sample, Kim and Nam introduce the creative tourism among the tourism industry branches as a profitable industry in South Korea [16]. Carvalho explored the main characteristics of the supply side of creative tourism and listed some resources used for the development of creative tourism, which are both tangible and intangible. Carvalho mentioned, i.e. creative culture, creative spectacles, creative spaces and creative tourism. He established strategies for the development of this type of tourism in Portugal's cities [17]. Regional urban development theorists Franco Bianchini and Charles Landry are famous for having written concerning creative tourism to build innovative cities from urban planning, development and management perspectives [18]. Urban creativity requires infrastructures beyond the hardware infrastructure rather a combination of the hard and soft infrastructures. The latter includes a city's strategy. The strategy leads the city to benefits new opportunities and potential businesses, particularly the creative tourism [19]. Åke Anderson and David Batten found that over the last millennium the great structural changes of production, location, trade, culture and institutions have happened. They suggest that the changes have most likely been caused by steady alterations to those logistical networks, which are responsible for the movement of the key factors of production [20]. They analyzed the characteristics of recent emerged economies based on innovations.

As pioneer futurists' scholars, they theorized a classic shift away from traditional quantitative methods of productions towards qualitative innovative productions. Additionally, Greg Richards throughout his paper titled Tourism development trajectories describes recent trends in creative tourism 
development. He also suggested some methods to relate the creativity and tourists' number enhancement. He wrote some samples, i.e. 'Workshops, experiences, open ateliers, itineraries, shop windows' [14]. Today, there are many ideas that the creativity in the tourism industry can come from any source including handicrafts, which are amazing human heritages. Thus, the paradigm of the tourism industry is under transformation from a traditional tourism to a creative tourism. Traditional tourism as has been said earlier is mass tourists, who will enjoy their free time at various attraction places. However, not all tourists satisfy the traditional tourism. There are many tourists would participate in local cultures, creative activities and experience regional/local lifestyles. The latter trend has been named creative tourism and scholars insist that the mass tourists trend will be changed to creative tourism in short time [21]. Here, a question arises; what is a creative tourism? UNESCO defined the term, as "A creative tourism is a journey that takes tourists to the practical experience and commitment through collaborative learning in local art spaces, heritages and unique arts such handicrafts. In the other word, a creative tourism communicates between tourists and native people, who builds a living culture". The global organization of the Creative Tourism Network has listed benefits of creative tourism as follows:

a. Cultural enrichment.

b. Positive impact on the confidence of residents in local tourism sites.

c. The revival of the tangible and intangible heritage.

d. Diversification of tourism activities.

e. Positive impact on the profitability of the cultural infrastructure because it creates new demands.

f. Introducing new patterns of tourism with increasing the value chain and high added value.

g. Authenticity and sustainability of the tourist sites.

h. The sure distribution of the tourism activities during the year.

i. Economic growth.

j. Creating jobs.

The development of the creative tourism at every site needs to develop the creative industries, active participation of tourists and close contact between tourists and local people. Also, in this type of tourism, the role of managers in recognition of creativity as a resource and an opportunity to attract tourists is important. Therefore, creative tourism is based on empirical activities and deep interactivity with the lifestyles of destinations.

\section{Importance of Handicraft Tourism Industry}

Handicrafts are an indication of regional/local culture and art. Handicrafts are applied and popular arts. Major scholars are arguing concerning the importance of handicraft businesses and positive impacts of handicrafts in attracting tourists, developing tourism industry, growing the local/regional economies and creating job opportunities. Britton analyzed the influence of handicrafts in the political economy. He found that 'The Third World destinations can increase their negotiating power, compress the rich profit space of multinationals, and achieve the market value of their handicraft products' [22]. Mitchell and Reid also studied handicrafts' effect in community integration. They looked at the community integration in tourism in terms of decision-making power processes, to control type and the number of local people employed in the local tourism sector [23]. From other side, Abisuga-Oyekunle and Fillis analyzed the role of handicrafts micro-enterprises for youth employment. They illustrated key findings from semi-structured interviews with local producers and buyers of handicraft products in the South Africa. The findings proved the contribution of the handicrafts for more job opportunities [24].

Many scholars studied the creative tourism from various perspectives. For samples, Sezgin and Gumus evaluated the positive role of handicrafts in ecotourism, and Kirsten and Rogerson explored the linkages of small enterprise development and handicrafts tourism $[25,26]$. The scholars focused on the importance of handicraft industries in the new emerging tourism. One aim of the creative tourism is to encourage production of handicrafts. 'Creativity is widely employed in the creative and cultural industries'. Without doubt, the interactive workshops that are held in small groups, allowing the tourists to discover their talents and creativity while they are associating with native people. The Creativity is widely employed in the creative and cultural industries as well [27]. Such workshops have usually rich natural, artistic, and cultural values.

\section{Competitions to Increase Share of the Tourism Industry with the Help of Handicrafts}

Economic competitiveness among regions and cities is a complex strategy in the present world. One stage of the economic competitiveness is tourism industry, which occurs in a variety of ways and contexts. Several economists suggest ideas on enhancing the competitiveness with the help of small firms working with handicrafts, particularly those located in tourist destinations [28,29]. Pike studied the destination marketing and recognized that the handicraft industries empowered tourism and increased the number of tourists in sake of creative handicrafts. Dwyer named some elements of a successful tourism industry, including the ability to invest in handicraft productions, which the recent tourists are interesting in. The above-mentioned scholars and many others believe that the handicraft tourism is one of the activities with the greatest potential for expansion on local and regional scales. The handicrafts assist the tourism sites to compete with other regions owing to their varieties, growth potentials, intellectual meanings, physical beauty and being consumable in tourism destinations. Consequently, the empowered competitive ability increases the local/regional shares in the tourism industry. As 
clusters of handicraft industries are competiveness devices in regional tourism development, the region will increase its share $[30,31]$.

\section{The Theoretical Framework of Economic Growth Through the Creative Tourism}

The second section of this paper aimed at setting a theoretical framework to examine the hypothesis of this research. The theory claims that handicraft industries contribute to the creative tourism at a time where the creative tourism is expanding in this network era. This event causes regional economic growth and development. Summarizing the discussions of this section suggests that tourism has been an important activity in human history. Additionally, the summation illustrates that the creative tourism is developing in this network time. Then, the principles and advantages of tourism resources have been spotlighted. Later, the importance of handicraft industries in the expansion of the creative tourism has been illustrated. Finally, this part discussed the regional competitions to get a better share in the global tourism industry. Figure 1 sums up the theoretical framework of this research.

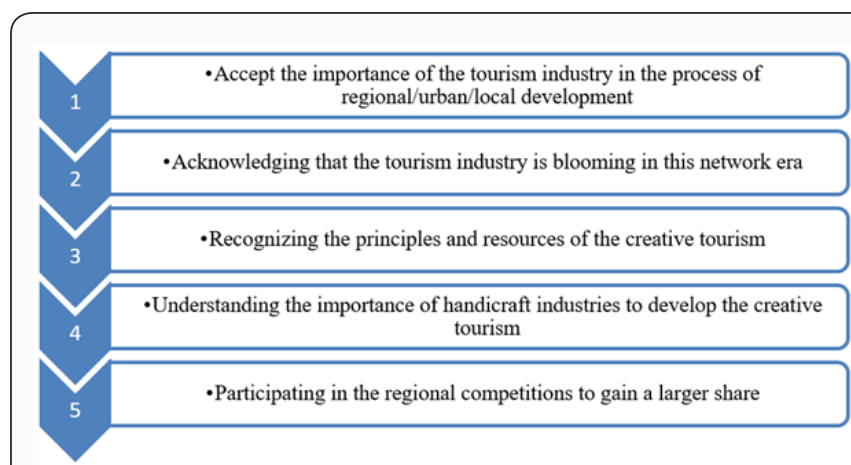

Figure 1: Summarized theoretical framework to make economic development with the help of the creative tourism.

\section{Case Studies}

\section{Characteristics of Shiraz City}

Shiraz is located in the southwest of Iran on a seasonal river called for "Roodkhaneye Khoshk. Figure 2 illustrates the place of Shiraz.

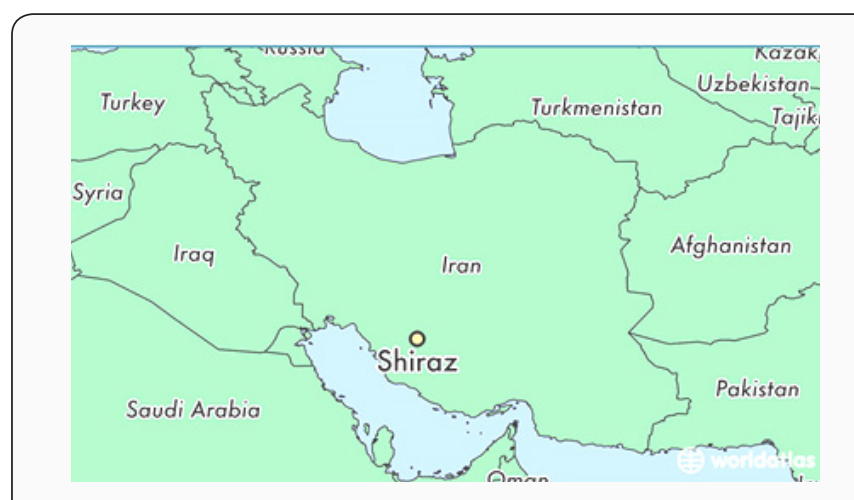

Figure 2: The place of Shiraz on the map of Iran and neighboring countries.
Shiraz is the center of Fars province in an almost rectangular shaped plain area in $29^{\circ}$ degrees north latitude and $52^{\circ}$ degrees east longitude. Shiraz population in 2011 amounted to 1, 460, 665 people (Statistic Center of Iran). Shiraz has a moderate climate and has been a regional trade center for over a thousand years. Shiraz is one of the oldest cities of ancient Persia. 'Shiraz is known as the city of poets, literature, wine and flowers' (Cameron, 1948). It is also considered by many Iranians to be the city of gardens, due to the many gardens and fruit trees that can be seen in the city. Shiraz has a lot number of tourism striking sites such Karim-Khan castle, Eram garden, Bazaar of Shiraz, Hafezieh (tomb of Hafez the old philosopher and poem), Sa'dieh (Tomb of great Sa'di the old author and poem), Persepolis site, Hammam-e Vakil (Bath of Vakil), Pasargadae (Cyrus the Great's Tomb), Cube of Zoroaster, etc.

\section{The Economic Importance of Tourism Industry in Shiraz}

Tourism is a multifaceted industry in Shiraz [32]. Jeon and colleagues studied employment opportunities and tax revenues that the tourism had made in Shiraz [33]. From a regional/ local point of view, tourism supports the improvement of the quality of life of Shiraz's native people too [34]. Tourism has been a source of social-economic change in many cities of Iran and Shiraz as well. Related to this Rastghalam and colleagues explored the socioeconomic changes have been made by the tourism industry. They found that 'the 'art and culture' factor provides a foundation for the cultural industries that are at the center of activities within Creative Cities. Therefore, cultural industries should be considered a key pillar' [35]. The tourism growth provided significant economic benefits such as creating employment and additional income in Shiraz [36-40]. Aref also found that the tourism industry has many positive environmental and social effects. Aref assessed the improvement rates of Shiraz inhabitants' life quality caused by tourism industry growing. He studied the effects of four groups of indicators, namely; health and safety well-being, emotional well-being, community well-being, and material well-being on the quality of life in Shiraz city. The study concluded, 'All the indicators show that the respondents have rather positive attitudes toward tourism impacts in their quality of life in Shiraz'.

Shiraz Opportunities and Strengths to Compete for the Creative Tourism Industry

Without doubt, Shiraz is an important center of handicraft industries. Observations show that the city is the home of various handicrafts. Many artists and innovative people working in different branches of handicrafts and create amazing innovative productions. The statistics show that the handicraft tourism is a significant driving machine to make economic growth in Shiraz. Table 2 reports the number of artist workers in every type of handicraft productions.

As illustrated by Table 2, some 65285 artists and innovative workers create various qualitative handicraft productions. The 
number is almost one twentieth of the total Shiraz's population. The fact means that creative handicraft productions are significant in Shiraz's urban economy and those able to attract tourists. This importance comes from the exporting, job creation and development inherent, which the handicraft productions have got in Shiraz.

Table 2: Numbers of employees in the various handicrafts manufacture.

\begin{tabular}{|c|c|}
\hline Type of handicraft & Number of workers occupied \\
\hline Kilim weaving & 25000 \\
\hline Weaving & 750 \\
\hline Burl wood & 600 \\
\hline Crocheted & 450 \\
\hline Traditional embroidery & 400 \\
\hline Wood & 330 \\
\hline Embroidery & 150 \\
\hline Pottery and ceramics & 70 \\
\hline Woodturning & 20 \\
\hline Joinery & 15 \\
\hline Other disciplines & 37500 \\
\hline Total artist workers & 65285 \\
\hline
\end{tabular}

\section{Discussions and Findings}

We asked the tourists how much they know Shiraz's crafts. The answers revealed that about 90 percent of tourists do not know the crafts of Shiraz. The interpretation of this result is the fact that marketing has not been performed and tourists are not informed at all! Thus, many incomes, which could be absorbed through this industry and grow Shiraz' urban economy and the creative tourism are lost. We also asked the tourists how much they buy Shiraz's crafts. See the results in Table 3.

Table 3: Amount of money the tourists are willing to pay for Shiraz' crafts.

\begin{tabular}{|c|c|}
\hline The amount of paid in Shiraz/ US\$ & Percent of tourists \\
\hline$>800$ & 20 \\
\hline $600-800$ & 40 \\
\hline $400-600$ & 20 \\
\hline $200-400$ & 20 \\
\hline
\end{tabular}

Table 3 shows that the 40 percent of the tourists paid about 600-800 \$ to buy crafts in Shiraz. While, $20 \%$ of tourists paid, between 200 to $\$ 400$, and 20 percent of them 400 to $\$ 600$ and only $20 \%$ of the tourists paid more than $\$ 800$. The results explain that despite the advantages of the Shiraz's crafts such as historical and global reputation, the revenue of the creative tourism in Shiraz is so little compared to other countries. The question is what does motivate the tourists to buy crafts in Shiraz? The answers are summarized in Table 4.

Table 4 reports that the motivation of 60 percent of tourists to purchase were aesthetic of the handicrafts. This is a fantastic result for Shiraz's crafts, which the regional planners should use it. Given the economic, social and cultural importance of crafts, several problems must be solved [41-44]. The artisans' respondents say the following measures should be considered to develop the creative tourism in Shiraz:

Table 4: Various motives of tourists, who purchase handicrafts goods.

\begin{tabular}{|c|c|}
\hline Motivations of Tourists to buy shiraz's Crafts & Percentage \\
\hline Using their beauty & 60 \\
\hline Completing some decorations & 20 \\
\hline Completing some Collections & 20 \\
\hline
\end{tabular}

a. Establishing contacts with the world tourism center

b. Supplying required technologies and equipment for handicrafts manufacture

c. Performing scientific national and international marketing

d. Participation of tourists in local activities

e. Participation of tourists in the production process of handicrafts

f. Increasing quality and beauty of the productions

g. Insisting in the uniqueness and variety of productions

h. Holding permanent and seasonal crafts exhibitions

i. Introducing Shiraz's handicraft products to tourists and regional people

j. $\quad$ Setting fair price

k. Ensure better functioning products

l. The emphasis should be on education, knowledge and research \& development

We calculated the rates of relationships among the 12 factors listed above. We also calculated the amount of money that tourists had purchased. We understood through our theoretical surveys and on ground experiences that relationships are significant. Therefore, we assessed the relationships among factors such: tourists' familiarity with the handicraft product before buying, beauty of products, the specific function of the product, variety of products, and tourists' participation in the process of production with the amount of money tourists are willing to pay for the productions. Using the ideas of people involved in the tourism activities and the Friedman test, we analyzed and measured the 12 effective factors in Shiraz's creative tourism. We present the results of our measurements in the form of rank Friedman test scores in Table 5.

The results in Table 5 show that the highest average rating impact of the creative and handicrafts tourism belongs to the variable of "Performing scientific national and international marketing" with an average score of 83.7. Then the variables 
of "Participation of tourists in the production process of handicrafts" and "Participation of tourists in local activities" with 83.4 and 83 scores respectively are major effective factors to develop the creative tourism in Shiraz. Increasing quality and beauty also ensuring the good functioning with 67.3 scores are important for the development. Other factors such educations, R\&D, establishing contact with famous global tourism agencies are significant as well. Furthermore, we calculated the Cronbach's alpha equal to $0.82(\alpha=0.82)$, which proves a high ranked dependency among the 12 considered variables. The interpretation of the 0.82 score for $\alpha$ is that the 12 variables have an interactive function and should be mitigated collectively to bloom the creative tourism in Shiraz and to meet the economic development.

Table 5: Scores of Friedman coefficient for 12 important factors of handicrafts in Shiraz.

\begin{tabular}{|c|c|}
\hline $\begin{array}{c}\text { Factors important in Shiraz's creative } \\
\text { tourism }\end{array}$ & $\begin{array}{l}\text { Friedman test } \\
\text { score }\end{array}$ \\
\hline $\begin{array}{l}\text { Establishing contacts with the world tourism } \\
\text { centers }\end{array}$ & 17.7 \\
\hline $\begin{array}{l}\text { Supplying technologies /equipment for } \\
\text { handicrafts manufactures }\end{array}$ & 5.6 \\
\hline $\begin{array}{l}\text { Performing scientific national and } \\
\text { international marketing }\end{array}$ & 83.7 \\
\hline Participation of tourists in local activities & 82 \\
\hline $\begin{array}{l}\text { participation of tourists in production process } \\
\text { of handicrafts }\end{array}$ & 83.4 \\
\hline $\begin{array}{l}\text { Increasing of quality and beauty of the } \\
\text { productions }\end{array}$ & 67.3 \\
\hline $\begin{array}{l}\text { Insisting in the uniqueness and variety of } \\
\text { productions }\end{array}$ & 68 \\
\hline $\begin{array}{l}\text { Holding permanent and seasonal crafts } \\
\text { exhibitions }\end{array}$ & 33.6 \\
\hline $\begin{array}{l}\text { Introducing Shiraz's handicraft products to } \\
\text { tourists }\end{array}$ & 42.5 \\
\hline Setting fair prices & 9 \\
\hline Ensure better functioning products & 67.3 \\
\hline $\begin{array}{c}\text { Education, knowledge and research \& } \\
\text { development }\end{array}$ & 33.6 \\
\hline
\end{tabular}

\section{Conclusion}

The innovation of this study is its special attention to the typological changes of tourism by the time passing and particularly, the recent change of the mass tourism to the creative tourism. This new era's tourism answers to the needs of tourists. Why? Since the tourists are willing to participate in the local activities and make better communications. Both the international scholars and our field studies consider the culture, arts, crafts, native people's lifestyles and so on as the components of the creative tourism. Our hypothesis was that the improvement and blooming of the creative tourism's services for all tourists coming to Shiraz would lead to the regional/ urban/local socioeconomic development. We used wisdom and opinions of both tourists and local people involved in tourism services through a questionnaire and structured interviews. As a result, we discovered the problems, which hinder the development of handicraft industries. This paper studied the 12 variables, which are important to develop the creative tourism in Shiraz. We recognized that if these problems were solved the handicraft productions would increase quantitatively and qualitatively. The case study on Shiraz's handicrafts from a creative tourism point of view verified that the increasing of job opportunities and improving of the local economy are available via the creative tourism expansion. The calculation of the Pearson correlation index showed that all the 12 said problems must be solved collectively. For example, the marketing shall be done scientifically, and the active participation of tourists shall be realized. Only aftermath the required actions, the tourism industry will be developed and gives economic growth. Through this research, we found that the tourism industry should be knowledge based. The industry shall define and prioritize required R\&D projects. We also found that if Shiraz or other cities with good tourism destination facilities join to the global tourism centers such as UNESCO, Creative Cities Network, etc. would gain positive socioeconomic implications. We recommend supporting of the private firms, which produce handicraft goods. In addition, efficient, professional and skilled labor is requested.

Finally, we believe that the research model used in this paper, its results and its recommendations can be applied in all cities that have got cultural, historical and handicrafts tourism sites with prominent attractions.

\section{References}

1. Almeida-García F (2017) Analysis of tourism policy in a developing country: the case of Morocco. Journal of Policy Research in Tourism, Leisure and Events p. 1-21.

2. Friedman M (1940) A comparison of alternative tests of significance for the problem of $\mathrm{m}$ rankings. The Annals of Mathematical Statistics. 11(1): 86-92.

3. Mandal P, Vong J (2016) Development of Tourism and the Hospitality Industry in Southeast Asia. Springer, Berlin, Germany.

4. Ebrahimzadeh I, Daraei M (2014) Analysis of tourism facilities' distribution and its optimization based upon Ashworth-Tunbridge and Getz Models using GIS; case study: Semnan in historical silk route. Humanities and Social Sciences 2(3): 47-56.

5. Shahraki AA, Ebrahimzadeh I (2015) Programming for development of tourism industry using case studies. Cogent Business \& Management 2(1): 1121638.

6. Fernández MTF, Pablo-Marti F (2016) Industrial Competitiveness in MENA Countries: Current Strategic Directions. Handbook of Research on Comparative Economic Development Perspectives on Europe and the MENA Region pp. 152.

7. Scott D, Gössling S, Hall CM, Peeters P (2016) Can tourism be part of the decarbonized global economy? The costs and risks of alternate carbon reduction policy pathways. Journal of Sustainable Tourism 24(1): 52-72.

8. Telfer DJ, Sharpley R (2015) Tourism and development in the developing world. Routledge, UK.

9. UNWTO: United Nation of World Tourism Organization (2014) International Tourism to continue robust growth. 
10. De Vita G, Kyaw KS (2016) Tourism Specialization, Absorptive Capacity, and Economic Growth. Journal of Travel Research.

11. Cárdenas-García PJ, Sánchez-Rivero M, Pulido-Fernández JI (2015) Does tourism growth influence economic development? Journal of Travel Research 54(2): 206-221.

12. Kabassi K (2010) Personalizes recommendations for tourists. Journal of Telematics and Informatics 27: 51-66.

13. del Mar Alonso-Almeida M, Bremser K (2013) Strategic responses of the Spanish hospitality sector to the financial crisis. International Journal of Hospitality Management 32: 141-148.

14. Richards G (2011) Tourism development trajectories: From culture to creativity? Tourism \& Management Studies (6): 9-15.

15. Prince S, Ioannides D (2017) Contextualizing the complexities of managing alternative tourism at the community-level: A case study of a nordic eco-village. Tourism Management 60: 348-356.

16. Kim S, Nam C (2016) Opportunities and challenges for South Korean tourism and creative industries. Tourism and the Creative Industries: Theories, Policies and Practice pp. 102.

17. Carvalho RMF (2015) Paper presented at the IV International Congress on tourism-Tourism in the $21^{\text {st }}$ Century, organized by the Management School of the Polytechnic Institute of Cávado and Ave and held at the Platform of Arts and Creativity in Guimarães. Community based tourism festivals in the Médio Tejo Region, Portugal.

18. Rodríguez-García MJ, Mora CM, Yáñez CJN (2014) Cultural Strategies, Creativity, and Local Development in Spain. Can Tocqueville Karaoke 11: 121-134.

19. Gil-Garcia JR, Pardo TA, Nam T (2015) What makes a city smart? Identifying core components and proposing an integrative and comprehensive conceptualization. Information Polity 20(1): 61-87.

20. Andersson ÅE, Batten DF (1987) Creative nodes, logistical networks, and the future of the metropolis. Transportation 14(4): 281-293.

21. Lee J, Lee H (2015) Deriving Strategic Priority of Policies for Creative Tourism Industry in Korea using AHP. Procedia Computer Science, 55: 479-484.

22. Britton SG (1982) The political economy of tourism in the Third World. Annals of tourism research 9(3): 331-358.

23. Mitchell RE, Reid DG (2001) Community integration: Island tourism in Peru. Annals of tourism research 28(1): 113-139.

24. Abisuga-Oyekunle OA, Fillis IR (2016) The role of handicraft microenterprises as a catalyst for youth employment. Creative Industries Journal p. 1-16.

25. Sezgin M, Gumus M (2016) The Evaluation of Beysehir Lake National Park (Konya-Turkey) in the Framework Ecotourism. Forest 14: 16-8.

26. Kirsten M, Rogerson CM (2002) Tourism, business linkages and small enterprise development in South Africa. Development Southern Africa 19(1): 29-59.
27. Lazzeretti L, Capone F, Seçilmiş IE (2016) In search of a Mediterranean creativity. Cultural and creative industries in Italy, Spain and Turkey. European Planning Studies 24(3): 568-588.

28. Pike S (2007) Destination marketing organisations. Routledge, UK.

29. Dwyer L, Edwards D, Mistilis N, Roman C, Scott N (2009) Destination and enterprise management for a tourism future. Tourism management 30(1): 63-74

30. Hamdan M, Low KCP (2014) Ecotourism Development in Brunei Darussalam. Transnational Corporations Review 6(3): 248-272.

31. Roy S, Misra S (2012) New Model on Cluster Competitiveness in Tourism Industry. In Services in Emerging Markets (ICSEM), 2012 Third International Conference on, pp. 168-174.

32. Koliver MB (2014) A comparative study and assessment of investments in the hotel industry in Iran and Turkey (1992-2011). International Journal of Academic Research in Business and Social Sciences 4(9): 341 .

33. Jeon MM, Kang MM, Desmarais E (2016) Residents' perceived quality of life in a cultural-heritage tourism destination. Applied Research in Quality of Life 11(1): 105-123.

34. Puczkó L, Smith M (2011) Tourism-Specific Quality-of-Life Index: The Budapest ModelBudapest Model. In Quality-of-life community indicators for parks, recreation and tourism management, Netherlands, pp. 163-183.

35. Rastghalam M, Seidaiy E, Nouri H (2017) The Creative Village Approach as a Tool for Creating Village Futures. Journal of Futures Studies 21(3): 35-48.

36. Aref F (2011) The effects of tourism on quality of life: a case study of Shiraz, Iran. Life Science Journal 8(2): 26-30.

37. Cameron, George G (1948) Persepolis Treasury Tablets, University of Chicago Press, USA, pp. 115.

38. Creative Tourism Network.

39. Ferreira J, Estevao C (2009) Regional competitiveness of a tourism cluster: A conceptual model proposal. Encontros científicos-Tourism \& management studies p. 37-51.

40. Jacobs J (1969) The economy of cities. Random House, New York, USA.

41. Oxford English Dictionary ( $3^{\text {rd }}$ edn) Oxford University Press, UK.

42. Ratiu DE (2013) Creative cities and/or sustainable cities: Discourses and practices. City, culture and society 4(3): 125-135.

43. Statistic Center of Iran (2011).

44. Turok I (2004) Cities, regions and competitiveness. Regional studies 38(9): 1069-1083. 
This work is licensed under Creative Commons Attribution 4.0 License

DOI: 10.19080/GJAA.2018.05.555665

\section{Your next submission with Juniper Publishers} will reach you the below assets

- Quality Editorial service

- Swift Peer Review

- Reprints availability

- E-prints Service

- Manuscript Podcast for convenient understanding

- Global attainment for your research

- Manuscript accessibility in different formats

( Pdf, E-pub, Full Text, Audio)

- Unceasing customer service

Track the below URL for one-step submission https://juniperpublishers.com/online-submission.php 